\title{
KARAKTERISASI MOLEKULAR BAKTERI ASAM LAKTAT (BAL) DARI DADIH SUMATERA BARAT SEBAGAI PROBIOTIK UNTUK MENURUNKAN KADAR KOLESTEROL DAGING ITIK BAYANG (Anas Spp)
}

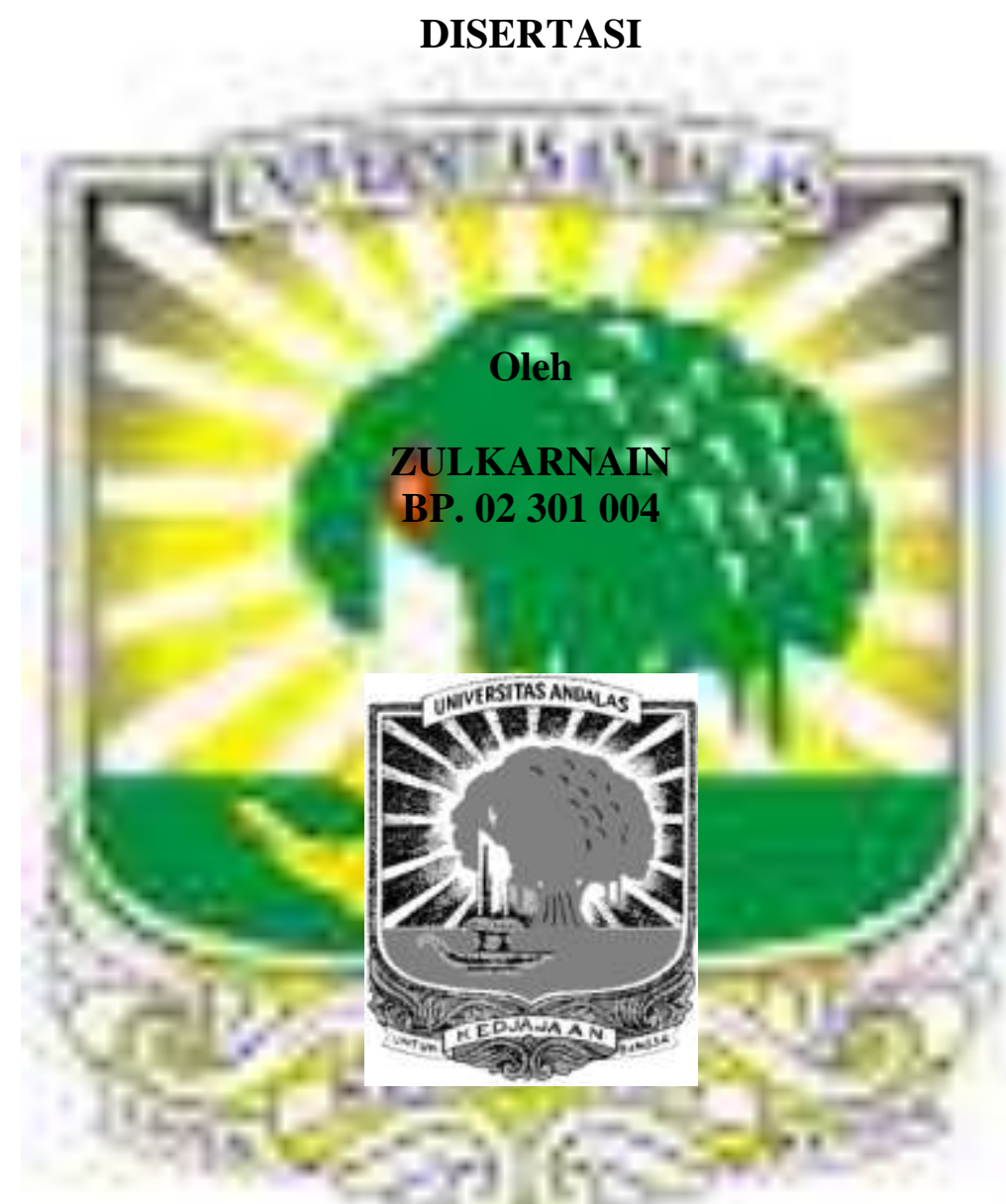

Pembimbing I: Prof.Dr.Ir.Yose Rizal.MSc Pembimbing II: Prof.Dr. Endang Purwati R.N Pembimbing III: Dr.Ir.Yan Heryandi.MS

PROGRAM STUDI ILMU PETERNAKAN PROGRAM DOKTOR FAKULTAS PETERNAKAN UNIVERSITAS ANDALAS 


\section{RINGKASAN}

ZULKARNAIN. Karakteristisasi Molekular Bakteri Asam Laktat (BAL) Dari Dadih Sumatera Barat Sebagai Probiotik Untuk Menurunkan Kadar Kolesterol Daging Itik Bayang (Anas Spp). Di bawah bimbingan Yose Rizal, Endang Purwati R.N dan Yan Heryandi.

Dadih merupakan makanan tradisional masyarakat Sumatera Barat yang berasal dari fermentasi alami susu kerbau di dalam tabung bambu oleh mikro organisme penghasil Asam laktat yang terdapat secara alami pada susu kerbau tersebut. Lima lokasi utama penghasil dadih di Sumatera Barat yaitu Kabupaten Sijunjung, Kabupaten Lima Puluh Kota, Kabupaten Agam, Kabupaten Solok, Kabupaten Tanah Datar. Itik Bayang sebagai sumber genetik yang dipelihara peternak di Kecamatan Bayang Kabupaten Pesisir Selatan. Probiotik adalah bakteri hidup yang diberikan kepada ternak, di dalam usus memberikan efek positif terhadap proses pencernaan dan sekaligus antagonis terhadp̣p pertumbuhan bakteri patogen.

Karakterisasi Molekular Bakteri Asam Laktat ( BAL) dari dadih Sumatera Barat. BAL dadih ini dimanfaatkan sebagai Probiotik untuk menurunkan kadar Kolesterol Daging Itik Bayang. Rangkaian penelitian telah dilakukan terhadap dadih Sumatera Barat. Penelitian tahap pertama adalah melakukan survey terhadap pengolahan dadih, bambu yang digunakan, daya simpan dan dilanjutkan dengan mengisolasi resistensi Anti Mikroba, karakterisasi identifikasi BAL dari dadih kerbau, mengidentifikasi morfologi dan pewarnaan gram, menguji kemampuan Bakteri Asam Laktat (BAL) terhadap beberapa bakteri patogen dan analisis aplikasi gen 16S rNA. Penelitian Tahap kedua bertujuan untuk uji Bakteri Asam laktat (BAL) yang diperoleh dari dadih sebagai probiotik untuk menurunkan kadar kolesterol daging itik Bayang. Rancangan yang digunakan adalah metoda acak lengkap pola faktorial. Faktor pertama (A) adalah dosis pemberian probiotik (BAL) yaitu dengan perlakuan A1 : Dosis $1 \mathrm{ml}$ probiotik (12.7 x $108 \mathrm{CFU} / \mathrm{g}) ; \mathrm{A} 2$ : Dosis $2 \mathrm{ml}$ probiotik (25.4 x $108 \mathrm{CFU} / \mathrm{g})$; A3 : Dosis 3 $\mathrm{ml}$ probiotik (38.1 x $108 \mathrm{CFU} / \mathrm{g})$. Faktor kedua (B) adalah frekuensi pemberian selama penelitian. Perlakuan B1 : Pemberian probiotik 0 kali; B2 : Pemberian probiotik 1 kali; B3 : Pemberian probiotik 2 kali; B4 : Pemberian probiotik 3 kali; B5 : Pemberian probiotik 4 kali; B6 : Pemberian probiotik 5 kali; B7 : Pemberian probiotik 6 kali. Setiap perlakuan terdiri atas 4 ulangan dan setiap unit ulangan terdiri atas 4 ekor itik. Jumlah itik yang digunakan sesuai dengan rancangan adalah sebanyak 346 ekor. Rancangan penelitian menggunakan model matematis menurut Steel dan Torrie (1993). Peubah yang diamati adalah konsumsi makanan, pertambahan bobot badan, konversi ransum, persentase karkas, kandungan Trigliserida dan kolesterol serta vili usus. Penelitian dilaksanakan di Kecamatan Koto Tangah, Kota Padang.

Hasil penelitian tahap pertama Bambu yang digunakan di Kabupaten Sijunjung, Kabupaten Lima Puluh Kota dan Kabupaten Agam sama yaitu Buluh hijau (Bambusa vulgaris Schad.Ex.Wend) mempunyai ciri-ciri sebagai berikut yaitu pelepah buluh hijau mudah luruh, kuping pelepah buluh bercuping keluar,tingginya mencapai $2 \mathrm{~cm}$, dengan bulu kejur mencapai $3 \mathrm{~mm}$ pada tepinya pelepah buluh tegak dengan pangkal melebar. Bambu ini dapat mencapai tinggi $30 \mathrm{~m}$, diameter 5-10 cm dengan panjang ruas $20-40 \mathrm{~cm}$. Untuk Kabupaten Solok 
dan Kabupaten Tanah Datar juga sama yaitu adalah Batuang (Dendrocalamus asper.Schult.f) backer ex.Heyme) dengan ciri-ciri bambu ini mempunyai rumpun yang agak sedikit rapat. Tinggi buluh dapat mencapai $20 \mathrm{~m}$ dan bergaris tengah 20 $\mathrm{cm}$. Dinding buluh cukup tebal yaitu $1-1,5 \mathrm{~cm}$, pelepah buluh mudah jatuh. Daya simpan Dadih sebagai berikut Dadih Kabupeten Sijunjung 5 hari, Kabupaten Lima puluh Kota 4 hari, Kabupaten Agam 5 hari, Kabupaten Solok 6 hari dan kabupaten Tanah Datar 7 hari. Total Koloni dadih sebagai berikut Kabupaten Sijunjung $1,90 \times 10^{8} \mathrm{CFU} / \mathrm{g}$, dadih Kabupaten Lima Puluh Kota $1,45 \times 10^{8}$ CFU/g, dadih Kabupaten Agam 2,89 x $10^{8}$ CFU/g, dadih Kabupaten Solok 2,31 x $10^{8} \mathrm{CFU} / \mathrm{g}$, dadih Kabupaten Tanah Datar 3,81 x $10^{8} \mathrm{CFU} / \mathrm{g}$. Hasil pewarnaan gram menunjukkan hasil gram positif dengan morfologi, dadih Kabupaten Sijunjung, Kabupaten Lima Puluh Kota, Kabupaten Solok, dan Kabupaten Tanah Datar berbentuk Coccus. Sedangkan dadih Kabupaten Agam berbentuk Bacillus.

Uji resistensi anti mikroba $\mathrm{BAL}$, terhadap 5 bakteri patogan (Lysteria monocytogenesis, Bacillus subtilis, Staphylococcus aureus, Eschericia coli, Salmonella typhii) mendapatkan bahwa dadih yang terbaik adalah dadih Kabupaten Sijunjung dan dadih Kabupaten Solok dengan nilai yang stabil dan konstan, yaitu dengan nilai zona hambat berkisar 8-14 mm. Dadih Kabupaten Lima Puluh Kota hanya mampu menghambat pertumbuhan bakteri Bacillus subtilis, Staphylococcus aureus, Salmonella typhii dan tidak mampu menghambat bakteri Lysteria monocytogenesis dan Salmonella typhii, pada kisaran nilai 1-7 mm. Dadih Kabupaten Tanah Datar hanya mampu menghambat pertumbuhan bakteri Lysteria monocytogenesis, Bacillus subtilis, Staphylococcus aureus, Salmonella typhii dan tidak mampu menghambat bakteri Salmonella typhii. Dari hasil uji laboratorium terhadap kemampuan menghambat pertumbuhan bakteri patogen antara Bakteri Asam laktat (BAL) dari dadih Kabupaten Sijunjung dan Kabupaten Solok yang digunakan sebagai biosuplement probiotik dan dapat menurunkan pertumbuhan bakteri patogen maka BAL dadih dari Kabupaten Sijunjung menghasilkan daya hambat bakteri patogen yang terbaik adalah BAL dadih dari Kabupaten Sijunjung.

Setelah dilakukan identifikasi BAL dari dadih di Sumatera Barat dengan menggunakan identifikasi $16 \mathrm{~S}$ rRNA maka pada Kabupaten Sijunjung ditemukan mikroba BAL dadih Pediococcus pentosaceus, Kabupaten Lima Puluh Kota ditemukan mikroba BAL dadih Enterococcus faecalis, Kabupaten Agam ditemukan mikroba BAL dadih Weissella paramesenteroides, Kabupaten Solok ditemukan mikroba BAL dadih Pediococcus pentosaceus dan Kabupaten Tanah Datar ditemukan mikroba BAL dadih Pediococcus pentosaceus. Kesimpulan dari penelitian tahap pertama BAL yang digunakan untuk penelitian tahap kedua adalah BAL Pediococcus pentosaceus yang berasal dari Kabupaten Sijunjung dengan konsentrasi $1,90 \times 10^{8} \mathrm{CFU} / \mathrm{g}$ yang memenuhi syarat sebagai probiotik.

Hasil penelitian tahap kedua, pengujian Biologis BAL Pediococcus pentosaceus berpengaruh nyata $(\mathrm{P}<.05)$ menurunkan kadar kolesterol daging itik Bayang Jantan (Anas Spp) dengan dosis $2 \mathrm{ml}$ dan frekuensi pemberian 5 kali dengan kandungan kolesterol 11,52 $\mathrm{mg} / \mathrm{dl}$, lebih baik dibandingkan dengan kandungan kolesterol kontrol $(42.48 \mathrm{mg} / \mathrm{dl} \pm 0.59)$. Dengan demikian terjadi penurunan kolesterol sebesar $72,88 \%$. Sedangkan kadar Trigliserida terendah $(44,45 \mathrm{mg} / \mathrm{dl})$ terdapat pada pemberian BAL dengan dosis $2 \mathrm{ml}$ dan Frekuensi pemberian 3 kali. Dibandingkan dengan kontrol terjadi penurunan sebesar 
41.94\%. Rata-rata konsumsi makanan tertinggi $(1340,67)$ g didapatkan dengan kombinasi pemberian dengan dosis $3 \mathrm{ml}$ dengan frekuensi 5 kali. Konsumsi makanan terendah $(995,79) \mathrm{g}$ didapatkan dengan kombinasi dosis $3 \mathrm{ml}$ dengan frekuensi 5 kali. Rata-rata pertambahan berat badan tertinggi (369,74 gram) didapatkan dengan pemberian BAL dosis $1 \mathrm{ml}$ dan frekuensi 5 kali. Persentase karkas tertinggi dengan dosis $3 \mathrm{ml}$ dan frekuensi 5 kali $(72,63 \pm 0,23 \%)$.

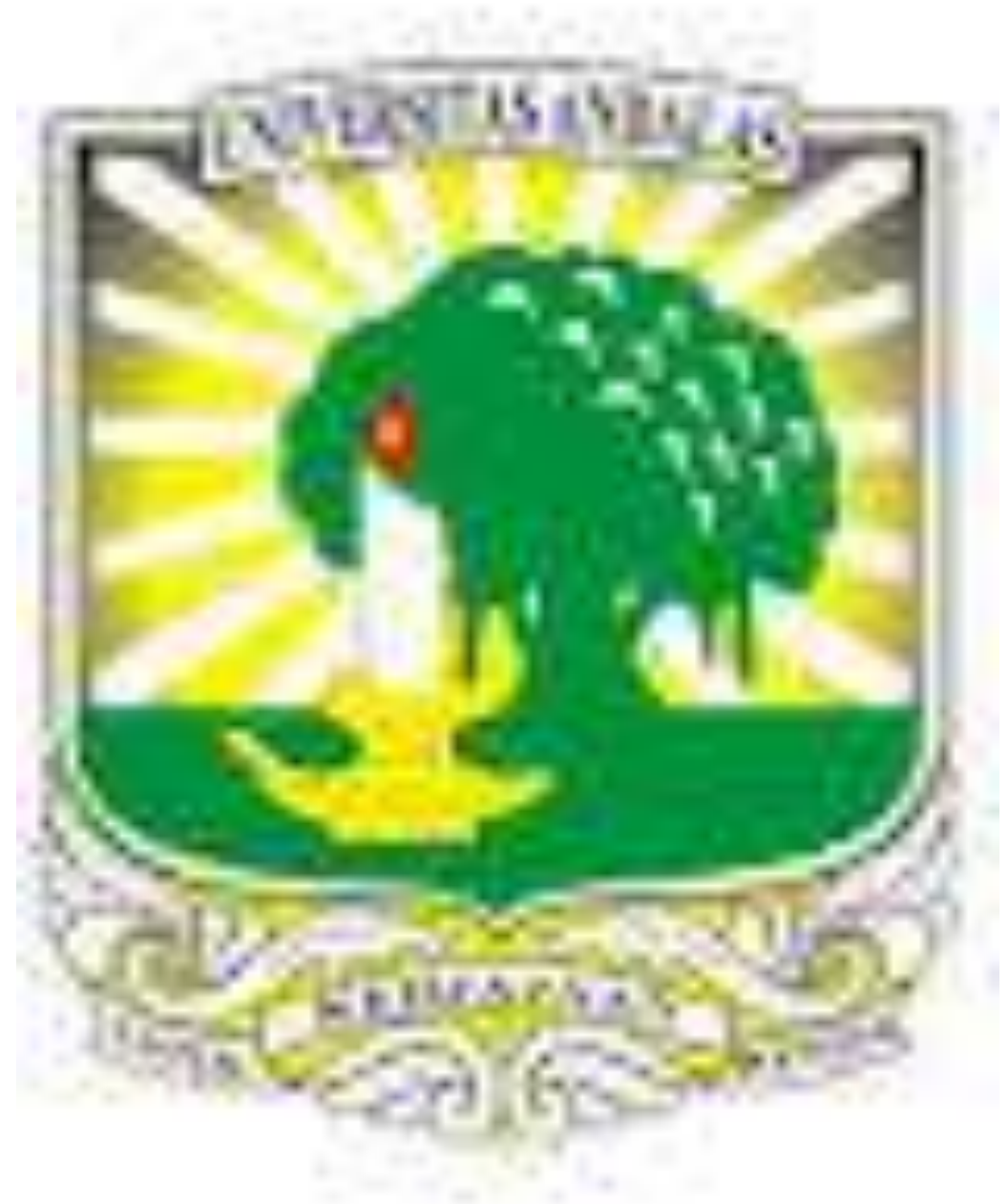

